\title{
Effect of chronic bronchitis on changes in pulmonary function caused by irradiation of the lungs
}

\author{
B. I. HOF F B A N D , ${ }^{1}$ P. M. S. GILLAM ${ }^{1}$ AND P. J.D. HEAF ${ }^{1}$ \\ From the Chest Department, University College Hospital, London
}

In a previous paper (Gillam, Heaf, Hoffbrand, and Hilton, 1964) it was shown that, contrary to widespread opinion, the presence of co-existing chronic bronchitis does not interfere with the treatment of bronchial carcinoma by radiotherapy. Patients with severe chronic bronchitis can be given the same dose of irradiation as those with mild bronchitis or with previously normal lungs. Survival after radiotherapy for bronchial carcinoma is not shortened by co-existing chronic bronchitis. The incidence of exacerbations of bronchitis both during and after radiotherapy is no more than might be expected in such a group of patients without irradiated lungs.

Chronic bronchitis has also been suggested as an aetiological factor in the development of radiation pneumonitis and fibrosis (Warren, 1942 ; Widmann, 1942 ; Rubin, Andrews, Paton, and Flick, 1958). The clinical study described in our other paper suggests that this is not the case. Serial pulmonary function tests have been used to investigate these problems further and the results are reported here.

\section{SELECTION OF PATIENTS}

Patients with bronchial carcinoma, treated by irradiation in the department of radiotherapy of University College Hospital, were classified on their past history, before lung function tests were done, into three main groups:

Group 1: No history of chronic chest symptoms. We have called these patients the nonbronchitic group.

Group 2: A history of chronic cough with mucoid sputum, often called by the patient a morning cough or smoker's cough, but without attacks of purulent bronchitis and without breathlessness. We have referred to these patients as the mild bronchitic group.

1 Present address: Whittington Hospital, Archway, London, N.19
Group 3: A history of chronic cough with sputum and recurrent chest infections or breathlessness or both. This group will be referred to as the severe bronchitic group. A subgroup 3a was derived from group 3 and consisted of those patients in group 3 with a forced expiratory volume in one second (F.E.V..$_{1.0}$ ) of $1,250 \mathrm{ml}$. or less. Group $3 \mathrm{a}$ thus consisted largely of those patients with the severest bronchitis of all.

Group 1 was similar to groups 2 and 3 in respect of age, sex, previous lung resections, and radiotherapy received. Group 1 , however, contained a higher proportion of patients with more extensive and more anaplastic tumours. Groups 2 and 3 were comparable in all respects (see Gillam et al. (1964) for full details).

\section{METHODS AND PROCEDURE}

The F.E.V.1.0 and forced vital capacity (F.V.C.) were measured with a low resistance spirometer (Bernstein, D'Silva, and Mendel, 1952). Duplicate maximal values were recorded. Diffusing capacity $\left(\mathrm{DL}_{\mathrm{co}}\right)$ was measured by a steady state carbon monoxide method (MacNamara, Prime, and Sinclair, 1959). Mixed venous $\mathrm{PCO}_{2}$ was estimated by the rebreathing method of Campbell and Howell (1960).

A semi-quantitative estimate of ventilation-perfusion inequalities in the lung was obtained from a record of the partial pressure of carbon dioxide $\left(\mathrm{PCO}_{2}\right)$ in the expired air (Comroe, Forster, Dubois, Briscoe, and Carlsen, 1962). The unpublished method used is based on the technique of Comroe and Fowler (1951) for estimating inequalities in ventilation. The $\mathrm{PCO}_{2}$ was measured throughout a full expiration from the end-inspiratory position using an instantaneous infrared carbon dioxide analyser. A simultaneous record of the volume of air expired was made. In this way it was possible to measure the rise in $\mathrm{PcO}_{2}$ in the expired air during expiration of $500 \mathrm{ml}$. $(750 \mathrm{ml}$. to $1,250 \mathrm{ml}$.). This rise in $\mathrm{PCO}_{2}$ is greater in the presence of more marked ventilation-perfusion inequalities, being normally less than $3 \mathrm{~mm}$. $\mathrm{Hg}$.

All the lung function tests were performed with the 
patient seated and at rest. They were carried out within one week of the start of treatment and at least four weeks after any thoracic surgery. The tests were repeated during and at the end of treatment, one month after the end of treatment, and at subsequent follow-up visits.

\section{RESULTS}

Table I (A) shows the number of patients in each group and their mean pre-treatment spirometry values. The differences between the mean F.E.V. $\cdot_{1.0}$ for each group were in the expected direction and statistically significant (group $1 v$. group $2, \mathrm{P}<0.05$; group $1 v$. group $3, \mathrm{P}<0.005$; group $2 v$. group 3 , $\mathrm{P}<0.05$ ). The differences between the mean F.V.C. values were less marked and statistically significant for groups 1 and 3 only $(P<0.05)$. These findings confirm the validity of the original clinical grouping and show that spirometry (and the F.E.V. in particular) detects differences caused by chronic bronchitis even in the presence of carcinoma.

It proved impossible to test every patient at the end of treatment and one month later. Table I (B) and (C) shows that the mean pre-treatment spirometry values of the patients who were re-

T A B L E I

PRE-TREATMENT SPIROMETRY

\begin{tabular}{|c|c|c|c|c|c|}
\hline & & $\underset{1}{\text { Group }}$ & $\underset{2}{\text { Group }}$ & $\underset{3}{\text { Group }}$ & $\underset{3 a}{\text { Group }}$ \\
\hline \multirow{3}{*}{$\begin{array}{l}\text { A } \\
\text { Patients } \\
\text { tested } \\
\text { before } \\
\text { treatment }\end{array}$} & No. & 18 & 47 & 47 & 20 \\
\hline & $\begin{array}{l}\text { Mean pre- } \\
\text { treatment } \\
\text { F.E.V.1.0 } \\
\text { (ml.) }\end{array}$ & 1,950 & 1,700 & 1,500 & 1,050 \\
\hline & $\begin{array}{l}\text { Mean pre- } \\
\text { treatment } \\
\text { F.V.C. } \\
\text { (ml.) }\end{array}$ & 3,000 & 2,700 & 2,600 & 2,050 \\
\hline \multirow{3}{*}{$\begin{array}{l}\text { B } \\
\text { Patients } \\
\text { tested before } \\
\text { and at the } \\
\text { end of } \\
\text { treatment }\end{array}$} & No. & 8 & 29 & 22 & 9 \\
\hline & $\begin{array}{l}\text { Mean pre- } \\
\text { treatment } \\
\text { F.E.V.1.0 } \\
\text { (ml.) }\end{array}$ & 1,900 & 1,700 & 1,450 & 1,050 \\
\hline & $\begin{array}{l}\text { Mean pre- } \\
\text { treatment } \\
\text { F.V.C. } \\
\text { (ml.) }\end{array}$ & 2,950 & 2,650 & 2,650 & 2,100 \\
\hline \multirow{3}{*}{$\begin{array}{l}\text { C } \\
\text { Patients } \\
\text { tested before } \\
\text { and one } \\
\text { month after } \\
\text { the end of } \\
\text { treatment }\end{array}$} & No. & 12 & 17 & 32 & 11 \\
\hline & $\begin{array}{l}\text { Mean pre- } \\
\text { treatment } \\
\text { F.E.V.1.0 } \\
\text { (ml.) }\end{array}$ & 1,950 & 1,750 & 1,550 & 1,050 \\
\hline & $\begin{array}{l}\text { Mean pre- } \\
\text { treatment } \\
\text { F.V.C. } \\
\text { (mi.) }\end{array}$ & 2,950 & 2,750 & 2,700 & 2,100 \\
\hline
\end{tabular}

The number of patients in $B$ and $C$ for each group does not add up to the number in A, as some patients had follow-up spirometry on both occasions and some had none.
T A B L E I I

DETAILS OF TREATMENT

\begin{tabular}{|c|c|c|c|c|c|}
\hline & & $\underset{1}{\text { Group }}$ & $\underset{2}{\text { Group }}$ & $\underset{3}{\text { Group }}$ & $\underset{3 a}{\text { Group }}$ \\
\hline \multirow[t]{2}{*}{ Whole group } & $\begin{array}{l}\text { Average } \\
\text { tumour } \\
\text { dose } \\
\text { (r units) }\end{array}$ & 3,000 & 3,500 & 3,350 & 3,400 \\
\hline & $\begin{array}{l}\text { Average } \\
\text { length of } \\
\text { treatment } \\
\text { (days) }\end{array}$ & 34 & 36 & 36 & 36 \\
\hline \multirow[t]{2}{*}{$\begin{array}{l}\text { Patients } \\
\text { tested at } \\
\text { beginning } \\
\text { and end of } \\
\text { treatment }\end{array}$} & $\begin{array}{l}\text { Average } \\
\text { tumour } \\
\text { dose } \\
\text { (r units) }\end{array}$ & 3,000 & 3,500 & 3,200 & 3,550 \\
\hline & $\begin{array}{l}\text { Average } \\
\text { length of } \\
\text { treatment } \\
\text { (days) }\end{array}$ & 37 & 35 & 33 & 36 \\
\hline \multirow{2}{*}{$\begin{array}{l}\text { Patients } \\
\text { tested at } \\
\text { beginning } \\
\text { and one } \\
\text { month after } \\
\text { treatment }\end{array}$} & $\begin{array}{l}\text { Average } \\
\text { tumour } \\
\text { dose } \\
\text { (r units) }\end{array}$ & 3,100 & 3,500 & 3,500 & 3,950 \\
\hline & $\begin{array}{l}\text { Average } \\
\text { length of } \\
\text { treatment } \\
\text { (days) }\end{array}$ & 35 & 39 & 37 & 39 \\
\hline
\end{tabular}

tested correspond closely, for each group and at each follow-up time, to these values for the group $\frac{}{\Phi}$ as a whole. The mean dose and length of treat- $\overrightarrow{\vec{P}}$ ment figures also show that these cases were representative of the complete groups in terms of $\frac{J}{\sigma}$ treatment received (Table II). We think, on the basis of these figures, that the selection of patients for follow-up tests was not biased.

The mean F.E.V.$_{1.0}$ and F.V.C. were higher than the initial values for all groups, both at the end of $\frac{x}{\sigma}$ treatment and one month later (Table III). The 3 improvement was similar in all groups, being, if anything, rather greater in the more bronchitic patients. Scattergrams were constructed for each 0 group plotting absolute changes in F.E.V. $\cdot_{1.0}$ and F.V.C. at the end of treatment and one month later against the pre-treatment values. These showed no correlation in any group. There is thus $\sigma$ no evidence that the mean figures conceal any $N$ trend for patients with poor respiratory function $\mathrm{N}_{\mathrm{C}}$ and bronchitis to deteriorate with irradiation.

The F.E.V..$_{1.0}$ is a measure of airways obstruction which is the most specific functional change in chronic bronchitis. There is therefore no evidence that patients with chronic bronchitis undergoing radiotherapy for carcinoma of the $\overline{0}$ bronchus suffer increased airways obstruction.

Figure 1 shows the changes in $\mathrm{DL}_{\mathrm{co}}$ during and $\frac{\Omega}{\mathrm{D}}$ at the end of treatment and one month after treat- ․ ment, expressed as a mean percentage of the initial values. All groups show a fall at one month 8 
T A B L E I I I

CHANGES IN SPIROMETRY

\begin{tabular}{|c|c|c|c|c|c|c|c|c|c|}
\hline & & \multicolumn{2}{|c|}{ Group 1} & \multicolumn{2}{|c|}{ Group 2} & \multicolumn{2}{|c|}{ Group 3} & \multicolumn{2}{|c|}{ Group 3a } \\
\hline & & $\mathbf{A}(\%)$ & B (ml.) & $A(\%)$ & B (ml.) & $A(\%)$ & B (ml.) & $A(\%)$ & B (ml.) \\
\hline $\begin{array}{l}\text { End results in patients tested } \\
\text { before and at end of treatment } \\
\text { End results in patients tested } \\
\text { before and one month after the } \\
\text { end of treatment }\end{array}$ & $\begin{array}{l}\text { F.E.V.1.0 } \\
\text { F.V.C. } \\
\text { F.E.V.1.0 } \\
\text { F.V.C. }\end{array}$ & $\begin{array}{r}+5 \cdot 0 \\
+9 \cdot 3 \\
+11 \cdot 1 \\
+9 \cdot 3\end{array}$ & $\begin{array}{r}+110 \\
+15 \\
+120 \\
+175\end{array}$ & $\begin{array}{r}+11 \cdot 7 \\
+9 \cdot 5 \\
+8 \cdot 2 \\
+11 \cdot 7\end{array}$ & $\begin{array}{l}+200 \\
+245 \\
+135 \\
+295\end{array}$ & $\begin{array}{r}+7 \cdot 9 \\
+9 \cdot 3 \\
+10 \cdot 7 \\
+8 \cdot 3\end{array}$ & $\begin{array}{r}+80 \\
+110 \\
+160 \\
+140\end{array}$ & $\begin{array}{l}+18 \cdot 5 \\
+21 \\
+20 \cdot 2 \\
+16\end{array}$ & $\begin{array}{l}+175 \\
+355 \\
+230 \\
+345\end{array}$ \\
\hline
\end{tabular}

$A=$ mean percentage change; $B=$ mean absolute change.

The apparent discrepancy in some cases between absolute and percentage changes is due to differences in the initial values, large percentages being associated with small absolute values and vice versa.

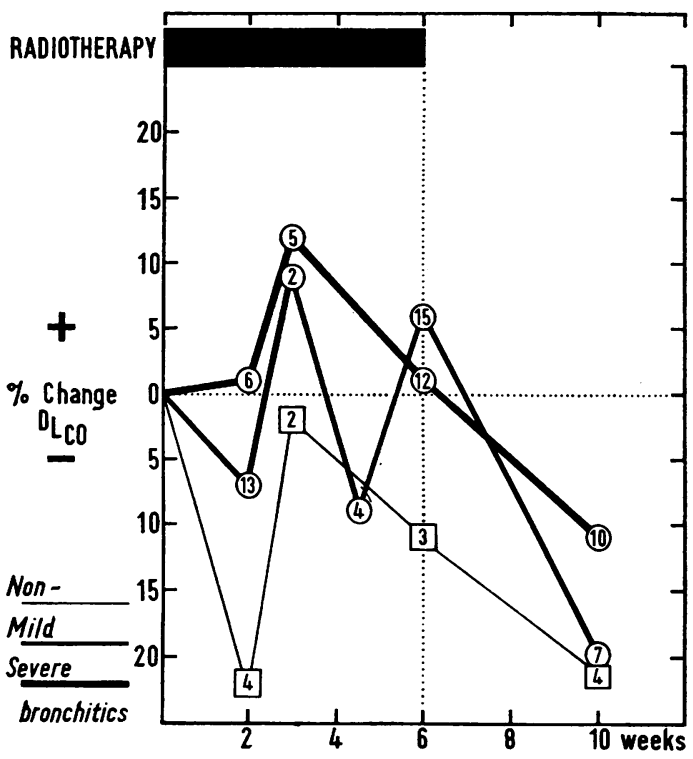

FIG. 1. Changes in $D_{\mathrm{Lco}}$ during and after treatment. The numbers on the graphs are the numbers of patients tested at each time. after treatment, this fall being least in the bronchitic group 3.

Scattergrams were constructed in which absolute changes from initial values in $\mathrm{DL}_{\mathrm{co}}$ were plotted against the initial F.E.V $\cdot_{1.0}$. These showed no significant relationship between the two parameters either at the end of treatment or one month later (Fig. 2). There is thus no evidence that the fall in $D_{c o}$ seen with radiotherapy is related to the presence of chronic bronchitis, judged clinically or by a low F.E.V.1.0 A scattergram was also constructed with changes from the initial $\mathrm{DL}_{\mathrm{co}}$ and expired $\mathrm{PcO}_{2}$ test values plotted against one another. This showed no correlation and thus suggests that the changes in diffusing capacity and ventilation-perfusion inequalities were not related.

The changes in mixed venous $\mathrm{PCO}_{2}$ from the initial values were small. There was a slight mean fall in $\mathrm{PCO}_{2}$ within the limits of experimental error for group 3 and for groups 1 and 2 considered together (Table IV). There is no suggestion from these figures that patients with chronic bronchitis tend to develop carbon dioxide retention during or after treatment. There is no evidence either of alveolar hyperventilation, which would be
FIG. 2. Changes in $D_{\text {Lco }}$ at one month after the end of treatment related to initial F.E.V.1.0. There is no correlation between these values.

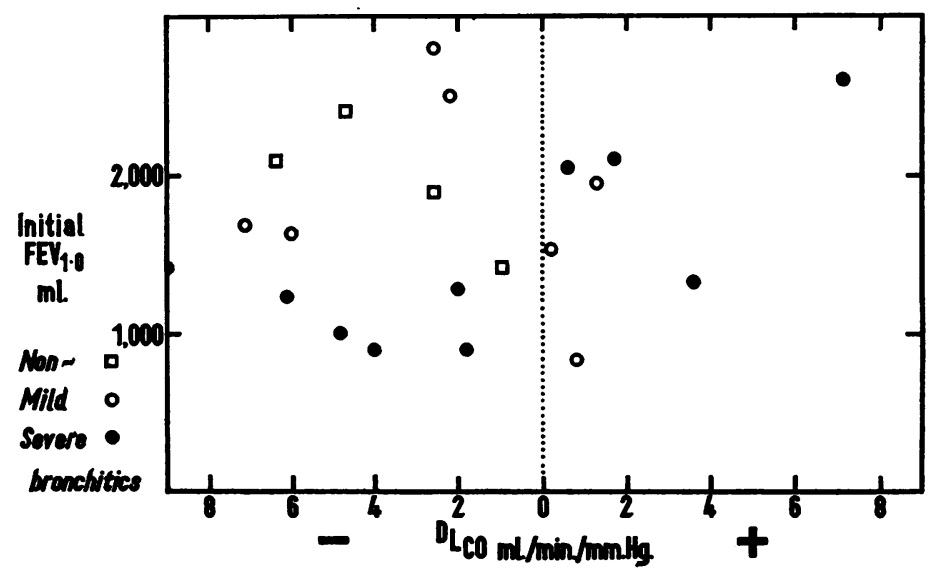


T A B L E I V

CHANGES IN MIXED VENOUS PCO, FROM PRE-TREATMENT VALUES

\begin{tabular}{c|c|c|c|c}
\hline & \multicolumn{2}{|c|}{ Groups 1 and 2 } & \multicolumn{2}{|c}{ Group 3 } \\
\cline { 2 - 3 } & $\begin{array}{c}\text { End of } \\
\text { Treatment }\end{array}$ & $\begin{array}{c}\text { One Month } \\
\text { after } \\
\text { End of } \\
\text { Treatment }\end{array}$ & $\begin{array}{c}\text { End of } \\
\text { Treatment }\end{array}$ & $\begin{array}{c}\text { One Month } \\
\text { after } \\
\text { End of } \\
\text { Treatment }\end{array}$ \\
\hline $\begin{array}{c}\text { No. of patients } \\
\text { tested at each } \\
\text { time }\end{array}$ & 14 & 9 & 8 & 8 \\
\hline $\begin{array}{c}\text { Mean change in } \\
\text { mixed venous } \\
\text { Pco }\end{array}$ & $\begin{array}{c}-1 \cdot 1 \\
(-6 \cdot 5 \text { to to } \\
+7)\end{array}$ & $\begin{array}{c}-2 \cdot 2 \\
(-8 \text { to } \\
+4)\end{array}$ & $\begin{array}{c}-2 \cdot 2 \\
(-8 \text { to } \\
+7)\end{array}$ & $\begin{array}{c}-10 \cdot 5 \text { to } \\
+4 \cdot 5)\end{array}$ \\
\hline
\end{tabular}

expected to occur if pulmonary fibrosis were developing.

The expired $\mathrm{CO}_{2}$ test is sufficiently sensitive to show the expected differences in the degree of ventilation-perfusion inequalities between groups 1,2 , and 3 (Table V). Thus, even in the complicating presence of bronchial carcinoma, the inequalities were greatest in the more severely bronchitic group 3 and least in the non-bronchitic group 1, the difference between the severe bronchitic and non-bronchitic groups being statistically significant. ${ }^{1}$ The mean percentage change in the expired

T A B L E V

EXPIRED $\mathrm{CO}_{2}$ TEST RESULTS WITH STATISTICAL COMPARISON OF MEAN VALUES

\begin{tabular}{|c|c|c|c|}
\hline & Group 1 & Group 2 & Group 3 \\
\hline 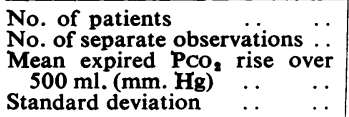 & $\begin{array}{r}4 \\
7 \\
2 \cdot 44 \\
0 \cdot 20\end{array}$ & $\begin{array}{r}11 \\
29 \\
3 \cdot 49 \\
1 \cdot 70\end{array}$ & $\begin{array}{r}8 \\
22 \\
4 \cdot 21 \\
2 \cdot 18\end{array}$ \\
\hline $\begin{array}{lll}\text { Group } 1 & v . \text { group } 2 \\
\text { Group } 1 & v . \text { group } 3 \\
\text { Group } 2 & v . \text { group } 3\end{array}$ & $\begin{array}{l}P<0.10 \\
P<0.025 \\
P<0.15\end{array}$ & & \\
\hline
\end{tabular}

$\mathrm{CO}_{2}$ test from the initial values was $+8.5 \%$ for 14 patients of all groups at the end of treatment and $-9 \%$ for seven patients one month later. The number of patients involved is too small to allow a comparison to be made between the groups. However, it appears that radiotherapy to the chest for carcinoma of the bronchus does not disturb ventilation-perfusion relationships significantly, at least not for up to one month after the end of treatment.

\section{RADIATION PNEUMONITIS}

Illustrative case report A 59-year-old man was found to have an inoperable oat-cell bronchial carcinoma.

1 Calculated using Student $t$ tables and applying Bessel's correction when small numbers are involved.
He gave a history of morning cough and sputum with occasional winter wheezing for years and was classified as group 2. Initial spirometry was F.E.V./F.V.C. $=$ $2,250 / 3,250$. A tumour dose of $4,400 \mathrm{r}$ was given by telecobalt over 39 days.

One week before the end of treatment he complained of breathlessness for the first time. This symptom increased over the next month, with night sweats, and at this time his chest radiograph showed marked unilateral radiation changes. Prednisone gave excellent symptomatic relief, but he died of carcinomatosis 28 weeks after the start of treatment.

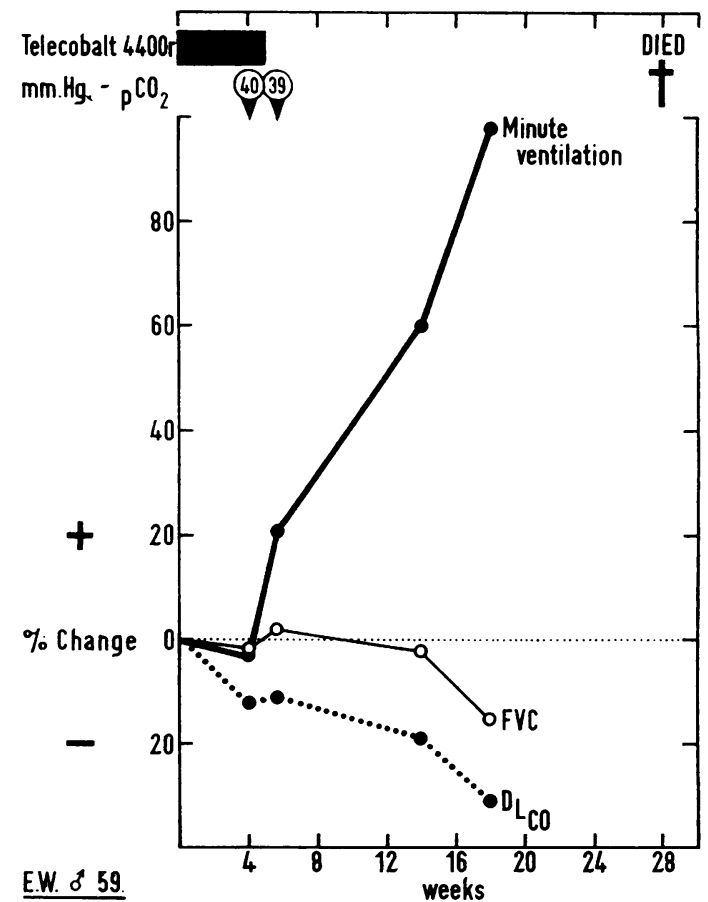

FIG. 3. Changes in lung function in a patient with radiation pneumonitis.

His lung function changes are shown in Figure 3. There was a large increase in minute ventilation with a low $\mathrm{PCO}_{2}$, a sharp fall in $\mathrm{DL}_{c o}$ from the onset of symptoms, and a less marked fall in F.V.C. These are the changes of the so-called 'alveolar-capillary block' syndrome.

\section{DISCUSSION}

There have been several investigations of the effect on lung function of radiotherapy for carcinoma of the bronchus (Catterall and Ogilvie, 1959 ; Sutton, 
1960 ; Deeley, 1960 ; Voutilainen, Mähönen, and Heinonen, 1962). In none has the possible significance of the frequently co-existing chronic bronchitis been considered and evaluated.

Like us, other workers have found an improvement in spirometric values in the first few months after the start of treatment (Sutton, 1960 ; Deeley, 1960). It seems reasonable to attribute these changes to shrinkage of the tumour. Such spirometric improvement might be expected to be greater in the non-bronchitic group 1 , in whom the tumours were more extensive and a greater proportion were anaplastic and presumably more radiosensitive. However, the spirometric changes were greater in the most severely bronchitic patients (group 3a). The mixed venous $\mathrm{PCO}_{2}$ changes also showed no tendency for the severely bronchitic patients to develop carbon dioxide retention compared with the mildly bronchitic and non-bronchitic cases. Patients with chronic bronchitis undergoing radiotherapy for carcinoma of the bronchus do not develop increased airways obstruction or alveolar hypoventilation. There is therefore no evidence of functional deterioration of chronic bronchitis during or after treatment.

The pulmonary function changes in established radiation pneumonitis and fibrosis are a combination of a restrictive defect and of the so-called alveolar-capillary block syndrome. There are reductions in the static lung volumes, a fall in the $\mathrm{DL}_{\mathrm{co}}$, hypoxaemia, and alveolar hyperventilation causing a reduced $\mathrm{PCO}_{2}$ (Stone, Schwartz, and Green, 1956; Emirgil and Heinemann, 1961). These workers have also found ventilation-perfusion inequalities in cases of radiation fibrosis uncomplicated by other lung disease. The lung volume changes found in our study show no tendency for patients with severe bronchitis to develop a restrictive abnormality. The $\mathrm{DL}_{\mathrm{co}}$ fell in all three groups, but the fall was least in the severely bronchitic patients of group 3. The $\mathrm{PCO}_{2}$ changes were small in all three groups, and there is no suggestion that patients with severe chronic bronchitis develop alveolar hyperventilation. This means that patients with chronic bronchitis undergoing radiotherapy for carcinoma of the bronchus show no special tendency to develop the lung function changes of radiation pneumonitis and fibrosis. This confirms the conclusions drawn on clinical grounds in our previous paper (Gillam et al., 1964).

It is now appreciated that the $\mathrm{DL}_{\mathrm{co}}$, as a measure of gas transference from lungs to circulation, depends on several factors apart from diffusion across the 'alveolar-capillary membrane'.
Among these factors are ventilation-perfusion ratios in the lungs. Indeed the functional changes in diffuse interstitial pulmonary fibrosis previously attributed to reduced alveolar-capillary diffusion can be fully explained by the presence of ventilation-perfusion inequalities (Holland, 1960 ; Finley, Swenson, and Comroe, 1962). There was no evidence, however, that the changes in $\mathrm{DL}_{\mathrm{co}}$ found in our patients were related to changes in ventilation-perfusion ratios. Alveolar exudate, thickening of alveolar septa, and vascular proliferative changes (which would reduce the pulmonary capillary bed) are frequent histological findings in irradiated lungs (Jennings and Arden, 1962). The acute radiation reaction also reaches its peak one to two months after irradiation (Cooper, Guerrant, Harden, and Teates, 1961). It seems possible, therefore, that the fall in $\mathrm{DL}_{\mathrm{co}}$ found in all groups one month after the end of treatment was due to subclinical radiation changes irrespective of the presence of chronic bronchitis.

\section{SUMMARY}

A serial lung function study has been made of patients having radiotherapy of the lungs for carcinoma of the bronchus. The changes found were compared in the three groups of patients, those without bronchitis, those with mild, and those with severe chronic bronchitis.

There is no evidence that patients with severe chronic bronchitis show any deterioration of the bronchitis ; nor do they show any greater tendency to develop the functional changes of radiation pneumonitis and fibrosis.

Gas transference tends to fall one month after the end of treatment in all patients irrespective of the presence of chronic bronchitis. This could represent a subclinical radiation reaction in the lungs.

We think that radiotherapy (as given at University College Hospital) should not be withheld from patients with severe chronic bronchitis for fear of exacerbating the bronchitis or inducing radiation pneumonitis and fibrosis.

We should like to thank Dr. M. Pike, of the Medical Research Council Statistical Research Unit, for considerable help with the statistics, Miss C. Faulkner and Miss A. Chamney for technical assistance, and Mr. V. K. Asta for preparing the figures.

This work was done during the tenure by two of us (P. M. S. G. and B. I. H.) of grants from the British Empire Cancer Campaign. 


\section{REFERENCES}

Bernstein, L., D'Silva, J. L., and Mendel, D. (1952). The effect of the rate of breathing on the maximum breathing capacity determined with a new spirometer. Thorax, 7, 255 .

Campbell, E. J. M., and Howell, J. B. L. (1960). Simple rapid methods of estimating arterial and mixed venous $\mathrm{pCO}_{2}$. Brit. med. J., 1 , 458.

Catterall, M., and Ogilvie, C. M. (1959). The effects of radiation on pulmonary function. Acta Un. int. Cancr., 15, 485

Comroe, J. H., Forster, R. E., Dubois, A. B., Briscoe, W. A., and Carlsen, E. (1962). The Lung, 2nd ed., p. 107. Year Book Medical Publishers, Chicago.

- - and Fowler, W. S. (1951). Lung function studies. VI. Detection of uneven alveolar ventilation during a single breath of oxygen. Amer. J. Med., 10, 408.

Cooper, G., Guerrant, J. L., Harden, A. G., and Teates, D. (1961) Some consequences of pulmonary irradiation. Amer. J. Roentgenol., 85, 865 .

Deeley, T. J. (1960). The effects of radiation on the lungs in the treat ment of carcinoma of the bronchus. Clin. Radiol., 11, 33

Emirgil, C., and Heinemann, H. O. (1961). Effects of irradiation of chest on pulmonary function in man. J. appl. Physiol., 16, 331.

Finley, T. N., Swenson, E. W., and Comroe, J. H. (1962). The cause of arterial hypoxemia at rest in patients with "alveolar-capillary block syndrome". J. clin. Invest., 41, 618 .
Gillam, P. M. S., Heaf, P. J. D., Hoffbrand, B. I., and Hilton, G. (1964). Chronic bronchitis and radiotherapy cf the lung. Lanceto 1,1245 .

Holland, R. A. B. (1960). Fhysiologic dead space in the Hamman Rich Syndrome: Physiologic and clinical implications. Amer. J $\overline{\bar{\eta}}$. Med., 28, 61 .

Jennings, F. L., and Arden, A. (1962). Develcpment of radiationत्ष pneumonitis. Arch. Path., 74, 351.

MacNamara, J., Prime, F. J., and Sinclair, J. D. (1959). An assess-0 ment of the steady-state carbon monoxide method of estimatinges pulmonary diffusing capacity. Thorax, 14, 166

Rubin, P., Andrews, J. R., Paton, R., and Flick, A. (1958). Response $\overrightarrow{0}$ of radiation pneumonitis to adrenocorticoids. Amer. J. Roent -1 genol., 79, 453 .

Stone, D. J., Schwartz, M. J., and Green, R. A. (1956). Fatal pul $\vec{\omega}$ monary insufficiency due to radiation effect upon the lung. Amer. J. Med., 21, 211.

Sutton, M. (1960). The functional effect of pulmonary irradiation. $\vec{x}$ Brit. m.ed. J., 2, 838

Voutilainen, A., Mähönen, H., and Heinonen, A. O. (1962). Effects of radiation on the lungs and pulmonary function in the treatment of carcinoma of the bronchus. Ann. Med. intern. Fenn., 51, suppl. 36.

Warren, S. (1942). Effects of radiation on normal tissues. V. Effects on the respiratory system. Arch. Path., 34, 917 .

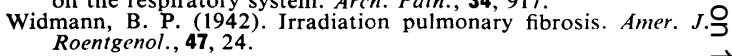

